\title{
From Closed to Open Innovation in Emerging Economies: Evidence from the Chemical Industry in Brazil
}

\author{
Elisa Thomas
}

\author{
"I know we would have much more benefits if we" \\ shared our problems. But, in general, we do not \\ explore partnerships as much as we should.
}

Purchasing Manager

(Interviewed for this study)

\begin{abstract}
In this article, we examine how firms in an emerging economy perform research and development (R\&D) activities in regards to the concept of open innovation. Most literature on open innovation shows multinational knowledge-intensive firms with wellestablished R\&D processes mainly in developed countries. Searching for management contributions for firms in emerging economies, we qualitatively analyzed two chemical firms in Southern Brazil that have different profiles and are representative samples of typical firms in the region. Our results show that firms did not fully exploit the potential benefits brought by open innovation, even when complete opening was not the main goal. The firms were similar concerning interactions with partners and stages where relationships occur. The generation of ideas was an open activity performed both by firms and by clients, and interactions with universities were getting stronger. On the other hand, intellectual property has not been used as means of profiting from innovation activities. Our main finding refers to the internal mediation of relationships with partners. R\&D teams rarely contact external organizations directly; instead, they leave such interactions to other departments within their firms. Relationships with clients are mediated through technical and commercial departments, and interactions with suppliers are intermediated by the supply staff.
\end{abstract}

\section{Introduction}

As competitive dynamics compel organizations to seek alternatives for survival and growth, the innovation process is constantly changing, and new ways of developing products, processes, services, and businesses are pursued (OECD/Eurostat, 2005). Theoretical models have been developed in the search for ways to understand how factors such as policy (Khan et al., 2016), culture (Hogan \& Coote, 2014), and leadership (Norbom \& Lopez, 2016), for example, shape the innovation process. Also, the locus of innovation is no longer studied as restricted to internal activities. Recent literature has been focusing on how firms carry out new product development by accessing and absorbing ideas and knowledge from outside the organization, as well as outsourcing to the market some internal discoveries and achievements (Bogers et al., 2017). It includes external relationships with other organizations such as competitors, customers, suppliers, universities, or research institutes (Nooteboom, 2008; Pittaway et al., 2004).

The open innovation approach has already been analyzed in many large multinational knowledge-intensive companies, such as Intel (Chesbrough, 2003), Procter \& Gamble (Huston \& Sakkab, 2006), Fiat (Ciravegna \& Maielli, 2011), Sony Mobile (Munir et al., 2017), and IBM (Dittrich et al., 2007) just to name a few. Most research on open innovation still approaches organizations and institutions in developed economies (e.g., Chesbrough, 2017; Lopez-Vega et al., 2016; Ullrich \& Vladova, 2016). However, even large firms practicing some elements of open innovation reported that they 


\section{From Closed to Open Innovation in Emerging Economies: Evidence from the Chemical Industry in Brazil Elisa Thomas}

were not satisfied with their processes for managing open innovation (Chesbrough \& Brunswicker, 2014). Regarding innovation activities from emerging economies, such as China and India, open innovation has been studied in terms of patents in co-authorship with inventors from different countries (Pai et al., 2012). In Brazil, open innovation has been studied in the aerospace industry (Dewes et al., 2010) and in a few large firms trying to structure their open innovation strategies as in the cases of Natura, the Brazilian subsidiary of IBM, and Siemens/Chemtech (Ades et al., 2013). Given that the open innovation model was initially adopted by multinational companies - and as a consequence, most of the literature concentrates on large firms located in developed economies - and given the increasing importance of partnerships for firms in emerging economies as ways to overcome barriers to innovation as the limitation of resources, it is a valuable exercise to explore how open innovation is being performed by firms located in emerging countries. We also take into consideration the suggestion of Bogers and colleagues (2017) regarding the emerging theme of "formal and informal organisational structures and managerial tools that support different forms of openness" when we research Brazilian firms from an intra-organizational perspective on open innovation. Therefore, the aim of this article is to analyze how local firms in an emerging economy such as Brazil are conducting $R \& D$ in regards to the open innovation concept.

In this article, we draw on empirical data from case studies in two chemical firms with different profiles located in Southern Brazil. The chemical industry was chosen for being one of the most import economic sectors in that regional innovation system, and in which competitive forces are highly relevant. Globally, the chemical industry has traditionally been dependent on R\&D activities to achieve competitive advantage. In fact, chemical firms were pioneers in establishing $R \& D$ departments and in performing internal research activities in the end of the 19th century (Walsh, 1984).

The article is organized as follows. We first lay out the theoretical foundations drawing on extant work from the broadly defined "open innovation" body of literature. The literature review discusses the concepts of closed and open innovation, and three main groups of differences were selected to be used as the analytical framework for the analysis of empirical cases. Second, we present a description of the research method and the profile of the firms. Finally, the cases are cross-analyzed to discuss some contributions for studies on innovation and implications for practice.

\section{Closed and Open Innovation}

Innovation processes have been studied for a long time and many methods have been described or prescribed in the literature (Christensen, 2006; Cooper, 1994; Utterback, 1994). Over the years, the organization of innovation activities has received extensive attention concerning how to transform an idea into a profitable product. The closed innovation model was the standard for firms in all industrial sectors until it started being challenged by a series of factors that caused the emergence of a more open manner of carrying out innovation activities (Chesbrough, 2003; Chesbrough et al., 2006). The classical perspective, in which R\&D activities are described mainly as internal processes of generating technology and products, can still be appropriated for firms that face stable environments with products of long technological cycles. However, in knowledge-intensive sectors, as in the chemical industry, for example, there are large gains from innovation and steep losses from obsolescence, and competition is best regarded as a learning race (Powell, 1998).

Relationships with external partners are powerful for innovation because $R \& D$ is, by nature, intensive in knowledge and benefits from the interaction of many actors internal and external to the organization (Nonaka et al., 2006). Suppliers are recognized as the best partners to know the products and processes of their clients (Brem, 2011; Hoegl \& Wagner, 2005; Klioutch \& Leker, 2011; Soosay et al., 2008), and clients are considered efficient creativity resources (Gassmann et al., 2005). Also, extensive work has been published about users (Baldwin \& von Hippel, 2011; Stockstrom et al., 2016; von Hippel, 2001) and universities (Bruneel et al., 2010; Freitas et al., 2013; Ramos-Vielba et al., 2010) as sources of complementary knowledge for innovation.

Overall, it is possible to identify a series of differences between open and closed innovation that goes beyond the discussion of where activities occur or the origins of the knowledge required to innovate. Chesbrough and colleagues (2006) consider several differences that we can organize into three groups: knowledge flow; changes in internal practices and intellectual property; and evaluation of innovation. Although the classification and the discussion of these differences yields a comprehensive and useful set of characteristics, they are also open to criticism. Table 1 summarizes the main aspects described by Chesbrough (2003), and several authors who follow the same line, with our own critical view about these characteristics. 


\section{From Closed to Open Innovation in Emerging Economies: Evidence from the Chemical Industry in Brazil Elisa Thomas}

Table 1. Differences between closed and open models of innovation

\begin{tabular}{|c|c|c|}
\hline Group of Practices & $\begin{array}{l}\text { Characteristics of } \\
\text { Closed Innovation }\end{array}$ & $\begin{array}{l}\text { Characteristics of } \\
\text { Open Innovation }\end{array}$ \\
\hline \multirow[t]{3}{*}{ 1. Knowledge flow } & $\begin{array}{l}\text { - External knowledge is } \\
\text { scarce, hard to find, and } \\
\text { hazardous to rely upon. }\end{array}$ & $\begin{array}{l}\text { - Useful knowledge is believed } \\
\text { to be widely distributed and of } \\
\text { generally high quality. }\end{array}$ \\
\hline & $\begin{array}{l}\text { - External knowledge plays a } \\
\text { useful but supplemental role } \\
\text { in innovation. }\end{array}$ & $\begin{array}{l}\text { - External knowledge plays an } \\
\text { equal role to internal } \\
\text { knowledge (Chesbrough et al., } \\
\text { 2006). }\end{array}$ \\
\hline & $\begin{array}{l}\text { knowledge and technology } \\
\text { are nonexistent } \\
\text { (Chesbrough et al., 2006). }\end{array}$ & $\begin{array}{l}\text { - Enabling outward flows of } \\
\text { technologies allows firms to } \\
\text { let technologies that internally } \\
\text { lack a clear path to the market } \\
\text { seek such a path externally. }\end{array}$ \\
\hline
\end{tabular}

Author's Reflections

- Advanced knowledge is not an exclusive attribute of firms adopting the open innovation model. Evidently, different sources of information decrease bounded rationality, but per se do not guarantee useful knowledge.

- Outbound flow of knowledge is conditioned by partner's absorptive capacities and previous knowledge.

\section{Changes of internal practices}

- Intermediary markets are rare.

- The business model limits choices of projects.

- Innovation processes are managed to reduce the chance of a Type 1 , or "false positive" evaluation errors.
- Parties can transact through an intermediary agent for activities that were previously conducted within firms (Kock \& Gözübüyük, 2011).

- Inventive output from within the firm should not be restricted to the current business model, but instead have the opportunity to go to market through a variety of channels (Chesbrough et al., 2006).

- The firm must incorporate processes to manage Type 2 , or "false negative" evaluation errors.
- Core competences developed internally may also induce new businesses (Prahalad \& Hamel, 1990).

- False positives may also be present in open innovation decisions.

\section{Intellectual property and evaluation of innovation activities}

- Intellectual property is a byproduct of innovation and is used defensively.

- Performance of the innovation process is measured by percentage of sales spent on (internal) R\&D; number of new products developed in the previous year, percentage of sales from new products; and the number of patents (West \& Bogers, 2017).
- The management of intellectual property plays a proactive role for innovation.

- Innovation performance is measured by R\&D outsourcing; time it takes for ideas to get to the market; rate of utilization of patents owned by the firm; and investments in outside firms.
- Intellectual property rights among partners increases transaction costs (Williamson, 1979).

- Actually, several open innovation practices may induce increasing transaction costs. 


\section{From Closed to Open Innovation in Emerging Economies: Evidence from the Chemical Industry in Brazil Elisa Thomas}

The first group of differences relates to the knowledge flow. In the closed innovation model, useful knowledge for $R \& D$ is considered to be rare in the market because firms try to keep it within their own walls. In open innovation, useful knowledge can be broadly distributed; that is why external knowledge plays an equal role to that afforded to internal knowledge in innovation activities. Prior to the spreading of the idea of open innovation, Cohen and Levinthal (1990) affirmed that the success in the introduction of new technologies depends on the marriage between the offer of knowledge and the competence of firms to efficiently absorb new equipment, systems, and productive processes. Also, in this group of characteristics, there is the intentional flow for externalizing knowledge that found no place internally in the organization. In open innovation, internal interests of different departments of the firm compete with foreign commercial channels to negotiate a new technology. These outward channels to market must be managed as real options for the use of new technologies because they allow the firm to obtain higher profits from innovation activities. Bounded rationality, of course, is diminished when different actors participate, but it does not necessarily guarantee success in new product development. Also, the presence of asymmetry of information and previous knowledge are related to different absorptive capacities among partners (Franco et al., 2014).

A second group of differences includes changes of internal practices in regards to the choice of projects and the use of intermediaries. Open innovation points to the emergence of intermediaries of relationships that are non-existent in closed innovation or have irrelevant roles (De Silva et al., 2017; Howells, 2006; Thomas et al., 2017). Innovation brokers allow firms to transact, at stages previously conducted within the firm, by connecting those seeking solutions with a rather large number of potential knowledge suppliers (Kock \& Gözübüyük, 2011).

In closed innovation, the centrality of the business model acts like a filter to limit the choice of projects and investments. Projects fitting the business model are accepted, and projects that do not fit the business model are not chosen to be developed (Chesbrough et al., 2006). This may lead to Type 1 or "false positive" errors when projects from R\&D go to commercialization but end up being a failure in the market. However, when it comes to research activities, there may appear discoveries outside the business model that escape the attention of the firm. Open innovation considers that such projects should not be abandoned "on the shelf" or cancelled. The organization must search for ways to exploit them, whether that means launching them into a new market or selling the technology to another firm. These cases are called Type 2 or "false negative" errors because the idea could turn into a success for its novelty, but a firm in closed innovation does not invest in developments outside the business model. In open innovation, firms should incorporate additional processes to manage "false negatives" with the goal of exploiting their value and should identify new potential markets for these projects. A closer look at Chesbrough's arguments reveals that, previous to his work, Prahalad and Hamel (1990) presented the concept of core competences and already considered that, in a closed innovation situation, the firm is able to develop knowledge that may induce new business and new markets.

The third difference refers to intellectual property and the evaluation of innovation activities. In open innovation, intellectual property represents a new class of assets that can deliver additional revenues, and also point the way towards entry into new businesses (Chesbrough et al., 2006). Open innovation states that the firm owning a technology and its patent may sell or license the intellectual property, thereby profiting from it.

Without protection, an innovation developed in cooperation with other organizations can present higher risks. In his studies, Chesbrough analyzes mainly the North American environment, where the intellectual property system is fully institutionalized. However, reality is different in other countries (Cassiman \& Valentini, 2016). Luoma, Paasi, and Valkokari (2010) found that a patent was an important protection method for only $30 \%$ of the 40 interviewed firms in Finland and in the Netherlands. In Brazil, the host country of our study, the culture of registering new developments is not common to most industrial sectors (Dewes et al., 2010; Etzkowitz et al., 2008). Therefore, we believe that, in countries where there is limited practice of protecting and negotiating intellectual property, this issue may be a limitation for the complete adoption of open innovation. The evaluation of innovation activities of a firm in an open innovation environment may also consider other activities with external partners besides the use of intellectual property, such as $R \& D$ outsourcing, time for ideas to get to the market, investment in spin-offs, etc. (West \& Bogers, 2017). It is important to note that Chesbrough's arguments give little attention to transaction costs inherent to joint projects. Opportunistic behaviour, bounded rationality, and information asymmetry (RemnelandWikhamn \& Knights, 2012; Williamson, 1979) may generate additional costs to open innovation. 


\section{From Closed to Open Innovation in Emerging Economies: Evidence from the Chemical Industry in Brazil Elisa Thomas}

As noted, open innovation activities offer different perspectives compared to a closed model; these differences will be analyzed in our case studies.

\section{Research Method}

This is a qualitative research study that uses multiple descriptive case studies (Eisenhardt, 1989; Eisenhardt \& Graebner, 2007). The research analyzes Brazil's Rio dos Sinos Valley, which includes around 20 cities and almost one million people. The region experienced fast economic development due to European immigrants who settled there in the 19th century and led the industrial development. Its most prosperous period was the 1970s when it became an important cluster of production and export of leather and footwear (Santos et al., 2017). However, since the mid-1990s, competitive pressures from other parts of the world and changes in foreign exchange rates have intensified competition based on prices. We look upon this change in the economy of the region, where chemical firms - previously supplying footwear firms - had to find new paths for their survival, and innovation became crucial.

The selection of cases started considering all the chemical firms in the region - a total of 25 firms. The first criterion for narrowing the focus was to identify firms with R\&D activities in the region, no matter the size of the firm. Among the remaining sample, the definition of cases considered the information provided by firms identifying open innovation activities. We followed what Seawright and Gerring (2008) call purposive selection of a representative sample. Two firms were chosen because they have distinct characteristics that enable analysis of different practices of relationships and a number of unique features particular to each firm. Companies A and B, both chemical firms, generally do not compete against one another because their product portfolios are different. The distinct features of the two case firms are described below, and their differences are summarized in Table 2:

- A branch of a foreign firm in Brazil and a Brazilian firm: Company A is a multinational organization focused on the production of chemical components. Headquartered in the Netherlands with subsidiaries in several countries, this case allows the study of the relationships among the headquarters and its international subsidiaries. Company A develops products for its local clients in Brazil and South America. Company B is a Brazilian firm, owned by a group of organizations in which each firm has a different business model and covers different stages in the value chain of the leather and footwear industry.

- A firm created from opportunity and a firm created from need: Company A opportunistically settled in Southern Brazil in 1993 to exploit the still strong manufacturing cluster of leather and footwear. Company B was established in 1969 to produce components for two footwear firms located in the Valley as a vertical integration strategy. At that time, the production of footwear in the region was strongly growing, driven by North American importers. But, there was a lack of available components for manufacturing due to the recent growth in the industry. Thus, Company B was established to fill this need for components, thereby enabling the broader vertical integration strategy.

Table 2. Main differences between the two case studies

\begin{tabular}{lll}
\hline Characteristic & Company & Company B \\
\hline Ownership & $\begin{array}{l}\text { Branch of a multinational firm based in the } \\
\text { Netherlands with subsidiaries in several } \\
\text { countries }\end{array}$ & $\begin{array}{l}\text { Headquarter of a Brazilian firm with two } \\
\text { manufacturing branches }\end{array}$ \\
\hline Foundation & $\begin{array}{l}\text { Established in 1993 in Brazil to exploit the strong } \\
\text { production cluster }\end{array}$ & $\begin{array}{l}\text { Established in 1969 to produce components for } \\
\text { two other firms }\end{array}$ \\
\hline $\begin{array}{l}\text { Market for innovation } \\
\text { at the time of research }\end{array}$ & $\begin{array}{l}\text { Product innovation for its current clients and } \\
\text { process innovation }\end{array}$ & Product innovation for a new market \\
\hline Interviewees & $\begin{array}{l}\text { R\&D manager; most senior researcher at the } \\
\text { firm; technical manager of an innovative } \\
\text { business unit; supply manager and coordinator } \\
\text { of contracts with suppliers. }\end{array}$ & $\begin{array}{l}\text { General manager; main researcher; another } \\
\text { consultant of ISO/TS 16949. }\end{array}$ \\
\hline
\end{tabular}




\section{From Closed to Open Innovation in Emerging Economies: Evidence from the Chemical Industry in Brazil Elisa Thomas}

\section{- A firm innovating to suit its current market and a firm innovating to suit a new market: Company A was in- vesting in product and process innovation for its cur- rent clients, especially the segment in which the firm is a market leader: synthetic laminates. Company B was investing in product innovation for a new mar- ket: the automotive industry.}

We conducted semi-structured interviews with managers and employees directly involved in innovation activities, typically across two interview sessions. We analyzed the cases based on recordings and transcripts of the interviews, which were supplemented by observations of internal meetings and documents such as internal reports, news and press releases on the firms' websites (Flick, 2002; Simons, 2009). The combination of different sources of data aimed at improving the research validity. When analyzing the data, we used our categories of analysis organized from the literature about relationships between organizations and other concepts of open innovation (Bansal \& Corley, 2011; Corley, 2012), as summarized in Table 1 . We related the empirical data to the theoretical literature to help interpret the findings.

We began the analysis of the cases by assessing the innovation process of each firm through two intra-cases studies. The categories of analysis from Table 1 were used to identify which activities were conducted internally or externally (for the "Knowledge flow" category) to understand how each firm chooses projects to develop, if and how the firms use intermediaries during innovation activities (for the "Changes of internal practices" category), how each firm deals with intellectual property and other protection methods and how each firm assesses its R\&D activities considering external partners (for the "Intellectual property and evaluation of innovation activities" category). We identified relationships with external organizations and the stages of $R \& D$ where such knowledge is sought and incorporated. Afterwards, the cross-analysis searched for complementary knowledge between the cases to open the possibility for a broad spectrum of conclusions.

\section{Cross-Case Analysis and Discussion}

First, a description of the flow of new product development considered stages of the innovation process and the internal and external relations in each step, as summarized schematically in Figures 1 and 2. In activities with more than one partner, the stronger relationships are highlighted in bold. In some activities, internal de- partments are the only partners. The arrows linking Companies A and B to external partners indicate the flow of knowledge with each partner: arrows pointing to one direction indicate the origin of the knowledge used for that $R \& D$ process (knowledge from the external partner into internal $R \& D$ of the case study) while arrows pointing both ways mean that there was a knowledge exchange that would benefit both partners.

As it can be seen from Figure 1, the amount of interactions at Company A decreases through the timeline of new product development. At the final part, the number of partners in each activity is smaller than at the beginning. Also, there are no new partners in the final stages all relationships occur with organizations with whom the Company A has been previously connected. Figure 2 illustrates the flow of new product development activities at Company B and its internal and external relationships. New product development in the automotive industry is ruled by ISO/TS 16949 Advanced Product Quality Planning (APQP). Therefore, some activities of the flow would be equivalent to APQP steps.

The inter-case analysis showed similar and divergent aspects of the opening (or not) of R\&D in both firms, as described in the sub-sections that follow.

\section{Knowledge flow}

We start by presenting the analysis of the first category from Table 1 regarding the knowledge flow with external partners:

- Relationship with clients: the firms interact with clients at the same stages, which are idea generation and final tests for the approval of new formulas. Both firms have the traditional process in which developments of new products are influenced by specific requests of customers, as described by Gassmann and colleagues (2005). Besides, there are some differences. Company A induces the opening of the innovation process of clients by suggesting how they can prepare their future collections. To be able to do so, Company A has a team of stylists who research fashion trends in many countries. The seasonality of products for winter and summer as well as the frequent changes in fashion goods produced by clients demand that developments of components are chronologically ahead of clients' launchings. In Company $\mathrm{B}$, products for the automotive industry are ruled by the international certification ISO/TS 16949. There is a formal systematic registration for relationships with clients regarding new product development. 


\section{From Closed to Open Innovation in Emerging Economies: Evidence from the Chemical Industry in Brazil Elisa Thomas}

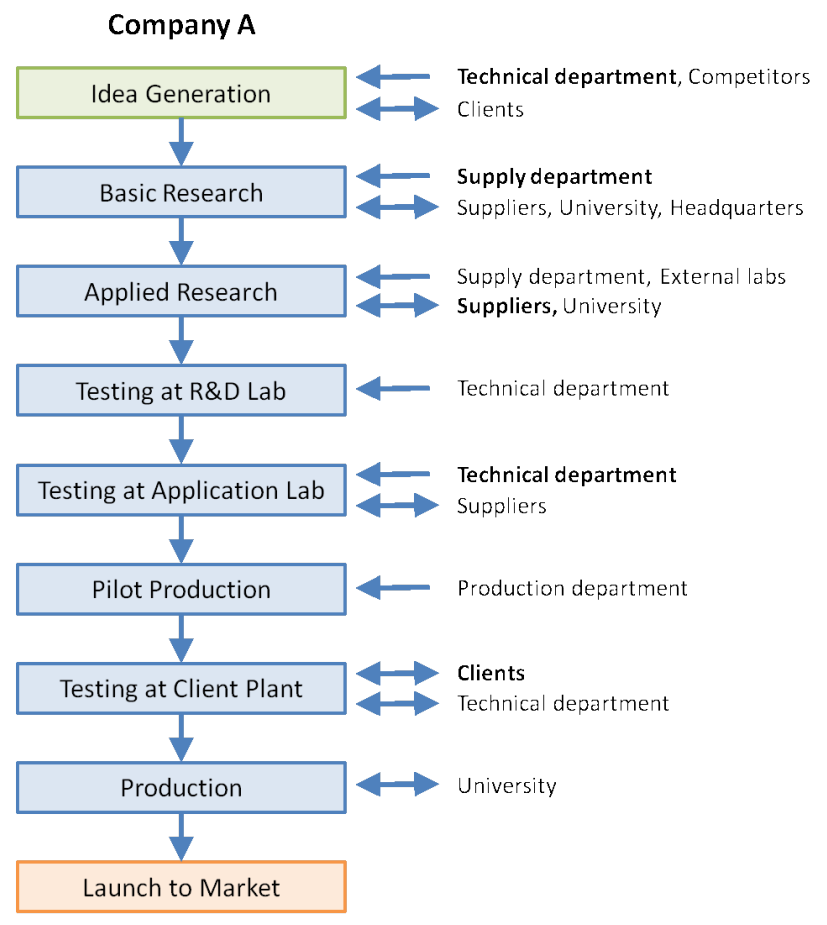

Figure 1. Internal and external relationships in Company A's innovation process

- Relationship with suppliers: the firms are related to their suppliers at the same stage of the innovation process, which is when new formulas are developed and tested. Also, the way of contact is similar, referring to the search for raw materials for new product development. In both firms, new product development provided inputs to suppliers in regards to new needs from clients. When Company B started the development of automotive products, it had a collaborative development with suppliers who helped to develop new formulas. The firm had parallel results from those mentioned by Hoegl and Wagner (2005), who found that strong buyer-supplier collaborations were "positively related with efficiency (development schedule and development cost) and effectiveness (product cost and product quality) of product development projects".

- Relationship with universities and research institutes: both firms have recently begun relationships with universities and research institutes. Company A invests in the academic development of staff by sponsoring a portion of their tuition fees for master's degrees, by encouraging informal relations with uni-

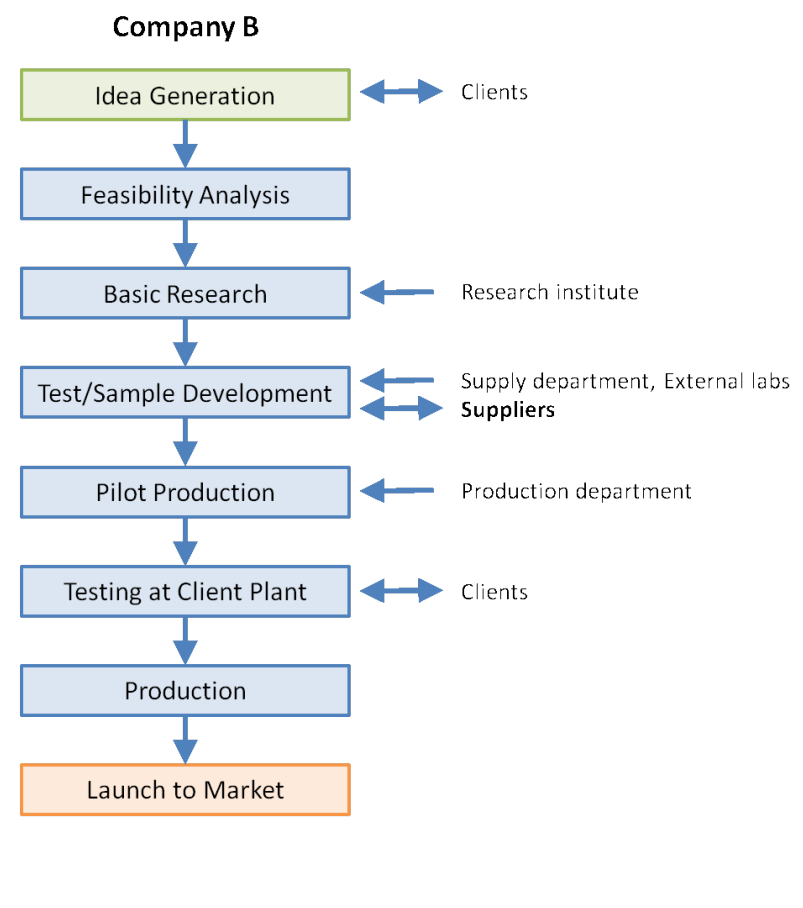

Figure 2. Internal and external relationships in Company B's innovation process

versity members, and by organizing staff visits to laboratories located on campus as well as visits of professors to the firm. Company A is moving closer to findings by Bruneel and colleagues (2010), who stated that good university-industry collaboration is fostered by trust between partners, informal reciprocity and exchange, face-to-face contacts, repeated interactions, and the involvement of a wide range of interaction channels. However, Company B has a different approach. Open innovation occurs when the firm hires an external laboratory to develop part of an innovation project. Company B had tried a joint development project with a Brazilian university, but it did not achieve the expected result. Afterwards, this project was transferred to a German research institute of applied sciences. The new contract outsourced the development of a new product, thereby replacing internal R\&D. Given that this development of a new product was directed toward the automotive industry, it relates to Chesbrough (2003), who pointed to the automotive industry as one of the industries in transition between closed and open innovation. However, we can see that the transition is happening in Brazil later than in developed countries studied by the author. 


\section{From Closed to Open Innovation in Emerging Economies: Evidence from the Chemical Industry in Brazil Elisa Thomas}

- Relationship with other units of the corporation: Company A maintains low-intensity relationships with its Dutch headquarters and with other organizations from the group. Company B does not interact with its branches for innovation. The other units of Company B's group are just production sites, located in other states of Brazil and abroad, where they are located to be closer to their clients.

- Relationship with other partners: the firms are related to external laboratories on the same stage of new product development, which is during applied research for the development of new formulations. Only Company A engaged in a relationship with competitors for the outward flow of knowledge, and it happened only once when a competitor approached Company A to negotiate a technology process. This may be a slight beginning of externalization flow of knowledge. Even so, considering the purposive outflow of knowledge to expand the markets for external use of innovation as one of the main concepts of open innovation (Chesbrough et al., 2006), both firms do not appropriate this practice as a way of profiting from their innovation.

\section{Changes of internal practices}

The analysis of the second category from Table 1 includes the choice of new $R \& D$ projects and the use of intermediaries:

- The choice of project to be developed: at Company A, the New Product Committee is responsible for the decision about starting a new product development project or interrupting an ongoing project. It includes managers from the departments of R\&D, supply, and sales of each business unit. According to the supply manager, the firm is not interested in investing in new product development in unknown fields. It operates in line with the closed innovation approach because the firm's current business model acts as a filter to choose new $R \& D$ projects (Chesbrough et al., 2006). At Company B, the meetings involve only the researcher and the director of the business unit. The first filter to evaluate an idea for a new product development checks whether the suggestion fits the firm's business technology line. This practice complies with the closed innovation approach and fits the concept of core competences (Prahalad \& Hamel, 1990). There is no concern from both firms to manage "false negative" errors in idea evaluation.
- Intermediation: in contrast to findings in recent literature (De Silva et al., 2017; Thomas et al., 2017), where intermediaries are external agents providing services for inter-organizational $R \& D$ projects, our research showed relationships intermediated by other departments of the firms. Relationships with external partners were not directly connected to $R \& D$ staff: relationships with suppliers occur through supply/purchasing departments in both firms. When the R\&D team needs new raw materials or different components, the supply department searches for the best option among suppliers connected to the firm or with different suppliers. Problems can happen in both firms when the supply department does not find a suitable component to incorporate in $\mathrm{R} \& \mathrm{D}$, because the R\&D team might consider using another material if they were in charge of this search. Staff from the supply department do not have enough knowledge about new product development to choose different options for new raw materials. At the same time, interactions with clients happen mainly through technical and commercial departments. When the client requests a new product, the technical or the commercial team registers the demand and its features. Afterwards, the request is passed to the R\&D department. Given that the technical staff is on the client's side, it sees needs and opportunities for new product development.

\section{Intellectual property and evaluation of innovation activities}

Finally, the third category from Table 1 analyzes intellectual property and the evaluation of innovation activities:

- The policy of the firms concerning intellectual property: Company A does not have the practice of registering the intellectual property of innovations, thus it fails to profit from any potential negotiation that might arise from it. Company B demonstrates concern about protecting innovation, as evidenced by its registration of intellectual property and publication of technical articles. Moreover, it sometimes intentionally does not register the intellectual property to maintain industrial secrecy. Patents are considered a by-product of innovation for Company B - as a way to establish ownership of the innovative products to be sold to clients. In our findings, both firms relate to the subject of intellectual property according to the closed innovation model (Chesbrough et al., 2006), and we confirm findings by Dewes and colleagues (2010), who point to the need for well-defined patenting policies in Brazilian firms. 


\section{From Closed to Open Innovation in Emerging Economies: Evidence from the Chemical Industry in Brazil Elisa Thomas}

- Evaluation of innovation activities: both firms assess their innovation activities in line with a closed innovation approach (Chesbrough et al., 2006), because innovation is not measured with consideration given to open innovation practices such as external contributions to the R\&D of the firm, investments in spin-offs, licensing of intellectual property, R\&D outsourcing, external paths to market for internal projects, or other practices.

\section{Conclusion}

The analysis of our cases contributes several insights to our understanding of how open innovation happens in firms in an emerging economy:

1. It is important to consider that open and closed models of innovation share complementary spaces in organizations and may even be simultaneous (as mentioned by Leminen et al., 2015).

2. Firms engage in relationships with other organizations in a variety of intensities and with different forms of interactions. The openness of the innovation process depends on the stage and activity of the flow of new product development. As seen in our cases, the early stages favour open innovation with a variety of partners more than stages nearer to commercialization. One of the reasons for this shift could be that uncertainty and risk are higher in the beginning of the process and, therefore, different knowledge sources are necessary to achieve innovation.

3. Openness also depends on the type of partner. It was found that openness is higher when firms establish partnerships for innovation with clients and universities.

4. Relationships for R\&D could be both tacit and explicit (Nonaka et al., 2006) through formal and informal means. Interviewees reported informal visits of university researchers to the firm's sites, as well as visits by the firm's researchers to university laboratories. Informal relationships also occur when technical staff visits clients. Formal relations can be exemplified by hiring external applied research.

5. Another contribution of the research refers to strong internal intermediation of relationships with external partners. Howells (2006) and Chesbrough's concepts do not mention mediated or indirect open innovation considering internal departments as in- termediaries. At the same time, literature on internal brokers focus on "individuals or teams who manipulate market knowledge to facilitate the process of internal transfer" (Cillo, 2005), which is a different role compared to the one found in our cases. The literature on innovation relates to the importance of gatekeepers and boundary spanners, but these internal mediators play a key role in helping firms to find the right partner with the right knowledge. In this sense, attention should be concentrated on the important role of internal agents linking internal departments to external sources of knowledge.

Although this research has focused on two chemical firms, it is possible to highlight some general recommendations for innovation managers based on our findings:

1. Open innovation should be part of the innovation strategy of the firm, as opposed to our cases, where relationships with external partners only occurred when the firm could not perform some R\&D activity by itself. Inflows and outflows of knowledge and technology should be considered as regular activities in the innovation process.

2. Firms belonging to conglomerates can better exploit other organizations within the same group to open $\mathrm{R} \& \mathrm{D}$ activities, given that secrecy is not considered an obstacle to open innovation in this environment. Considering open innovation strategies as a continuum, firms belonging to conglomerates collaborate with other firms from the same group but keep the core of their innovation processes in house, being characterized as semi-open innovation (BargeGil, 2010).

3. To better exploit the benefits of open innovation, firms should develop structured ways to interact with partners. For example: software used for internal $R \& D$ management could have some fields accessible by external partners; events where suppliers could present new materials related to the firm's products; or frequent interactions with universities' research groups in areas that could generate innovation for firms.

4. Firms should establishing mechanisms to exploit the results of innovation, allowing outward flows of technology in order to generate profits for the innovator. These mechanisms include protecting the intellectual property and, afterwards, licensing and commercializing it. 


\section{From Closed to Open Innovation in Emerging Economies: Evidence from the Chemical Industry in Brazil Elisa Thomas}

Despite presenting valuable insights on the process of open innovation in firms in emerging economies, this study does have its limitations. First, the findings are based on a limited set of case studies from the chemical industry. Second, we looked at practices from the firms' point of view, not by collecting data from external partners, which may have limited our understanding of certain situations related to partnerships.

In conclusion, the process of innovation is slowly shifting from a closed to an open model in firms from emerging economies. Some characteristics of the innovation process are common to firms, regardless of whether they are in developed or emerging economies, such as the diversity of knowledge needed to innovate, the impossibility of complete control of the state of art, the increasing investment demanded by R\&D activities, and the high risks involved. However, our findings show that some characteristics of the innovation process are particular to emerging countries, such as the lack of culture regarding the protection of intellectual property, which can limit some practices of open innovation.

\section{About the Author}

Elisa Thomas is a Post-Doctoral Researcher at the Centre for Innovation Research at the University of Stavanger in Norway. Previously she has worked as a teacher, a course coordinator, and a student's supervisor at Unisinos University in Brazil. Elisa completed her PhD at the Business School at Unisinos University, having spent one year at the University of Southampton for empirical research in the United Kingdom. Her research focusses on open innovation, innovation intermediaries, universityindustry partnerships and the role of universities in innovation systems.

\section{References}

Ades, C., Figlioli, A., Sbragia, R., Porto, G., Ary Plonski, G., \& Celadon, K. 2013. Implementing Open Innovation: The Case of Natura, IBM and Siemens. Journal of Technology Management \& Innovation, 8(S1): 57-57.

http://dx.doi.org/10.4067/S0718-27242013000300057

Baldwin, C., \& von Hippel, E. 2011. Modeling a Paradigm Shift: From Producer Innovation to User and Open Collaborative Innovation. Organization Science, 22(6): 1399-1417.

https://doi.org/10.1287/orsc.1100.0618

Bansal, P., \& Corley, K. 2011. The Coming of Age for Qualitative Research: Embracing the Diversity of Qualitative Methods. Academy of Management Journal, 54(2): 233-237.

http://psycnet.apa.org/doi/10.5465/AMJ.2011.60262792

Barge-Gil, A. 2010. Open, Semi-Open and Closed Innovators: Towards an Explanation of Degree of Openness. Industry and Innovation, 17(6): 577-607. https://doi.org/10.1080/13662716.2010.530839

Bogers, M., Zobel, A.-K., Afuah, A., Almirall, E., Brunswicker, S., Dahlander, L., Frederiksen, L., Gawer, A., Gruber, M., \& Haefliger, S. 2017. The Open Innovation Research Landscape: Established Perspectives and Emerging Themes across Different Levels of Analysis. Industry and Innovation, 24(1): 8-40. https://doi.org/10.1080/13662716.2016.1240068

Brem, A. 2011. Editorial: Special Issue on Open Innovation and the Integration of Suppliers - Part Two. International Journal of Innovation Management, 15(1): v-vii. http://dx.doi.org/10.1142/S1363919611003234

Bruneel, J., D'Este, P., \& Salter, A. 2010. Investigating the Factors that Diminish the Barriers to University-Industry Collaboration. Research Policy, 39(7): 858-868. https://doi.org/10.1016/j.respol.2010.03.006

Cassiman, B., \& Valentini, G. 2016. Open Innovation: Are Inbound and Outbound Knowledge Flows Really Complementary? Strategic Management Journal, 37(6): 1034-1046.

https://doi.org/10.1002/smj.2375

Chesbrough, H. 2017. The Future of Open Innovation: The Future of Open Innovation Is More Extensive, More Collaborative, and More Engaged with a Wider Variety of Participants. Research-Technology Management, 60(1): 35-38.

https://doi.org/10.1080/08956308.2017.1255054

Chesbrough, H., \& Brunswicker, S. 2014. A Fad or a Phenomenon? The Adoption of Open Innovation Practices in Large Firms. Research-Technology Management, 57(2): 16-25.

Chesbrough, H., Vanhaverbeke, W., \& West, J. 2006. Open Innovation: Researching a New Paradigm. Oxford University Press on Demand.

Chesbrough, H. W. 2003. Open Innovation: The New Imperative for Creating and Profiting from Technology. Boston, MA: Harvard Business School Press.

Christensen, C. M. 2006. The Ongoing Process of Building a Theory of Disruption. Journal of Product Innovation Management, 23(1): 39-55.

https://doi.org/10.1111/j.1540-5885.2005.00180.x

Cillo, P. 2005. Fostering Market Knowledge Use in Innovation: The Role of Internal Brokers. European Management Journal, 23(4): 404-412.

https://doi.org/10.1016/j.emj.2005.06.008 


\section{From Closed to Open Innovation in Emerging Economies: Evidence from the Chemical Industry in Brazil Elisa Thomas}

Ciravegna, L., \& Maielli, G. 2011. Outsourcing of New Product Development and the Opening of Innovation in Mature Industries: A Longitudinal Study of Fiat During Crisis and Recovery. International Journal of Innovation Management, 15(01): 69-93. http://doi.org/10.1142/S1363919611003088

Cohen, W. M., \& Levinthal, D. A. 1990. Absorptive Capacity: A New Perspective on Learning and Innovation. Administrative Science Quarterly: 128-152. http://doi.org/10.2307/2393553.

Cooper, R. G. 1994. Perspective Third-Generation New Product Processes. Journal of Product Innovation Management, 11(1): 3-14. https://doi.org/10.1016/0737-6782(94)90115-5

Corley, K. 2012. Publishing in AMJ-Part 7: What's Different about Qualitative Research? Academy of Management Journal, 55(3): 509-513.

https://doi.org/10.5465/amj.2012.4003

De Silva, M., Howells, J., \& Meyer, M. 2017. Innovation Intermediaries and Collaboration: Knowledge-Based Practices and Internal Value Creation. Research Policy, 47(1): 70-87. https://doi.org/10.1016/j.respol.2017.09.011

Dewes, M. d. F., Gonçalez, O. L., Pássaro, A., \& Padula, A. D. 2010. Open Innovation as an Alternative for Strategic Development in the Aerospace Industry in Brazil. Journal of Aerospace Technology and Management, 2(3): 349-360.

http://doi.org/10.5028/JATM.2010.02038910

Dittrich, K., Duysters, G., \& de Man, A.-P. 2007. Strategic Repositioning By Means of Alliance Networks: The Case of IBM. Research Policy, 36(10): 1496-1511.

http://doi.org/10.1016/j.respol.2007.07.002

Eisenhardt, K. M. 1989. Building Theories from Case Study Research. Academy of Management Review, 14(4): 532-550. http://doi.org/10.2307/258557

Eisenhardt, K. M., \& Graebner, M. E. 2007. Theory Building from Cases: Opportunities and Challenges. Academy of Management Journal, 50(1): 25-32.

http://doi.org/10.5465/AMJ.2007.24160888

Etzkowitz, H., Ranga, M., Benner, M., Guaranys, L., Maculan, A. M., \& Kneller, R. 2008. Pathways to the Entrepreneurial University: Towards a Global Convergence. Science and Public Policy, 35(9): 681-695. http://doi.org/10.3152/030234208X389701

Flick, U. 2002. Qualitative Research - State of the Art. Social Science Information, 41(1): 5-24.

https://doi.org/10.1177/0539018402041001001

Franco, C., Marzucchi, A., \& Montresor, S. 2014. Absorptive Capacity, Proximity in Cooperation and Integration Mechanisms. Empirical Evidence from CIS Data. Industry and Innovation, 21(4): 332-357. https://doi.org/10.1080/13662716.2014.942083

Freitas, I. M. B., Marques, R. A., \& e Silva, E. M. d. P. 2013. University-Industry Collaboration and Innovation in Emergent and Mature Industries in New Industrialized Countries. Research Policy, 42(2): 443-453.

https://doi.org/10.1016/j.respol.2012.06.006

Gassmann, O., Sandmeier, P., \& Wecht, C. H. 2005. Extreme Customer Innovation in the Front-End: Learning from a New Software Paradigm. International Journal of Technology Management, 33(1): 46-66.

https://doi.org/10.1504/IJTM.2006.008191.
Hoegl, M., \& Wagner, S. M. 2005. Buyer-Supplier Collaboration in Product Development Projects. Journal of Management, 31(4): 530-548.

https://doi.org/10.1177/0149206304272291

Hogan, S. J., \& Coote, L. V. 2014. Organizational Culture, Innovation, and Performance: A Test of Schein's Model. Journal of Business Research, 67(8): 1609-1621.

https://doi.org/10.1016/j.jbusres.2013.09.007

Howells, J. 2006. Intermediation and the Role of Intermediaries in Innovation. Research Policy, 35(5): 715-728. http://doi.org/10.1016/j.respol.2006.03.005

Huston, L., \& Sakkab, N. 2006. Connect and Develop. Harvard Business Review, 84(3): 58-66.

Khan, Z., Lew, Y. K., \& Akhtar, P. 2016. The Influence of Industrial Policy and National Systems of Innovation on Emerging Economy Suppliers' Learning Capability. Industry and Innovation, 23(6): 512-530.

https://doi.org/10.1080/13662716.2016.1189811

Klioutch, I., \& Leker, J. 2011. Supplier Involvement in Customer New Product Development: New Insights from the Supplier's Perspective. International Journal of Innovation Management, 15(01): 231-248.

Kock, C. J., \& Gözübüyük, R. 2011. The Impact of Innovation Brokers on Interfirm Network Evolution. IE Business School Working Paper 11-02. Madrid: IE Business School. https://doi.org/10.2139/ssrn.1798731

Leminen, S., Turunen, T., \& Westerlund, M. 2015. The Grey Areas between Open and Closed in Innovation Networks. Technology Innovation Management Review, 5(12): 6-18. http://timreview.ca/article/948

Lopez-Vega, H., Tell, F., \& Vanhaverbeke, W. 2016. Where and How to Search? Search Paths in Open Innovation. Research Policy, 45(1): 125-136. https://doi.org/10.1016/j.respol.2015.08.003

Luoma, T., Paasi, J., \& Valkokari, K. 2010. Intellectual Property in InterOrganisational Relationships-Findings from an Interview Study. International Journal of Innovation Management, 14(03): 399-414. https://doi.org/10.1142/S1363919610002702

Munir, H., Linåker, J., Wnuk, K., Runeson, P., \& Regnell, B. 2017. Open Innovation Using Open Source Tools: A Case Study at Sony Mobile. Empirical Software Engineering: 1-38. https://doi.org/10.1007/s10664-017-9511-7

Nonaka, I., Von Krogh, G., \& Voelpel, S. 2006. Organizational Knowledge Creation Theory: Evolutionary Paths and Future Advances. Organization Studies, 27(8): 1179-1208.

https://doi.org/10.1177/0170840606066312

Nooteboom, B. 2008. Learning and Innovation in Inter-organizational Relationships. In S. Cropper, C. Huxham, M. Ebers, \& P. S. Ring (Eds.), The Oxford Handbook of Inter-Organizational Relations: 607-634. Oxford: Oxford University Press.

Norbom, H. M., \& Lopez, P. D. 2016. Leadership and Innovation: Informal Power and Its Relationship to Innovative Culture. Journal of Leadership Studies, 10(1): 18-31. https://doi.org/10.1002/jls.21430

OECD/Eurostat. 2005. Oslo Manual: Guidelines for Collecting and Interpreting Innovation Data (3rd ed). Paris: OECD Publishing. 


\section{From Closed to Open Innovation in Emerging Economies: Evidence from the Chemical Industry in Brazil Elisa Thomas}

Pai, D.-C., Tseng, C.-Y., \& Liou, C.-H. 2012. Collaborative Innovation in Emerging Economies: Case of India and China. Innovation, 14(3): 467-476.

https://doi.org/10.5172/impp.2012.14.3.467

Pittaway, L., Robertson, M., Munir, K., Denyer, D., \& Neely, A. 2004. Networking and Innovation: A Systematic Review of the Evidence. International Journal of Management Reviews, 5(3-4): 137-168. https://doi.org/10.1111/j.1460-8545.2004.00101.x

Powell, W. W. 1998. Learning from Collaboration: Knowledge and Networks in the Biotechnology and Pharmaceutical Industries. California Management Review, 40(3): 228-240. https://doi.org/10.2307/41165952

Prahalad, C., \& Hamel, G. 1990. The Core Competence of the Corporation. Harvard Business Review, 68(3): 79-91.

Ramos-Vielba, I., Fernández-Esquinas, M., \& Espinosa-de-losMonteros, E. 2010. Measuring University-Industry Collaboration in a Regional Innovation System. Scientometrics, 84(3): 649-667. https://doi.org/10.1007/s11192-009-0113-z

Remneland-Wikhamn, B., \& Knights, D. 2012. Transaction Cost Economics and Open Innovation: Implications for Theory and Practice. Creativity and Innovation Management, 21(3): 277-289. https://doi.org/10.1111/j.1467-8691.2012.00639.x

Santos, M. L. L., Schmidt, S., Bohnenberger, M. C., \& Schreiber, D. 2017. Cultura e Governança nas Relações Interorganizacionais: Um Estudo de Caso do Cluster Calçadista do Vale dos Sinos. Perspectivas Contemporâneas, 12(2): 131-151.

Seawright, J., \& Gerring, J. 2008. Case Selection Techniques in Case Study Research: A Menu of Qualitative and Quantitative Options. Political Research Quarterly, 61(2): 294-308. https://doi.org/10.1177/1065912907313077

Simons, H. 2009. Case Study Research in Practice. London: SAGE Publications.

Soosay, C. A., Hyland, P. W., \& Ferrer, M. 2008. Supply Chain Collaboration: Capabilities for Continuous Innovation. Supply Chain Management: An International Journal, 13(2): 160-169. https://doi.org/10.1108/13598540810860994
Stockstrom, C. S., Goduscheit, R. C., Lüthje, C., \& Jørgensen, J. H. 2016. Identifying Valuable Users as Informants for Innovation Processes: Comparing the Search Efficiency of Pyramiding and Screening. Research Policy, 45(2): 507-516. https://doi.org/10.1016/j.respol.2015.11.002

Thomas, E., Marques Vieira, L., \& Balestrin, A. 2017. Mind the Gap: Lessons from the UK to Brazil about the Roles of TTOs throughout Collaborative R\&D Projects. BAR - Brazilian Administration Review, 14(4): e170048.

http://dx.doi.org/10.1590/1807-7692bar2017170048

Ullrich, A., \& Vladova, G. 2016. Weighing the Pros and Cons of Engaging in Open Innovation. Technology Innovation Management Review, 6(4): 34-40.

http://timreview.ca/article/980

Utterback, J. M. 1994. Mastering the Dynamics of Innovation: How Companies Can Seize Opportunities in the Face of Technological Change. Boston, MA: Harvard Business School Press.

von Hippel, E. 2001. Innovation by User Communities: Learning from Open-Source Software. MIT Sloan Management Review, 42(4): 82-86.

Walsh, V. 1984. Invention and Innovation in the Chemical Industry: Demand-Pull or Discovery-Push? Research Policy, 13(4): 211-234. https://doi.org/10.1016/0048-7333(84)90015-5

Williamson, O. E. 1979. Transaction-Cost Economics: The Governance of Contractual Relations. The Journal of Law and Economics, 22(2): 233-261.

https://doi.org/10.1086/466942

Citation: Thomas, E. 2018. From Closed to Open Innovation in Emerging Economies: Evidence from the (cc) BY Chemical Industry in Brazil. Technology Innovation Management Review, 8(3): 26-37.

http://doi.org/10.22215/timreview/1144

Keywords: open innovation, collaboration, R\&D, intermediary, emerging economy 


\section{Academic Affiliations and Funding Acknowledgements}

Canadà
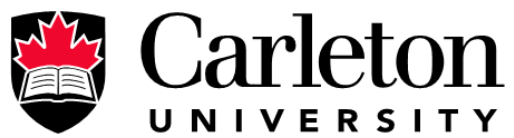

U N I V E R S I T Y

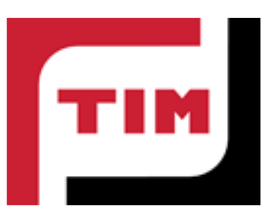

The Federal Economic Development Agency for Southern Ontario (FedDev Ontario; feddevontario.gc.ca) is part of the Innovation, Science and Economic Development portfolio and one of six regional development agencies, each of which helps to address key economic challenges by providing regionallytailored programs, services, knowledge and expertise.

- The TIM Review receives partial funding from FedDev Ontario's Investing in Regional Diversification initiative.

Technology Innovation Management (TIM; timprogram.ca) is an international master's level program at Carleton University in Ottawa, Canada. It leads to a Master of Applied Science (M.A.Sc.) degree, a Master of Engineering (M.Eng.) degree, or a Master of Entrepreneurship (M.Ent.) degree. The objective of this program is to train aspiring entrepreneurs on creating wealth at the early stages of company or opportunity lifecycles.

- The TIM Review is published in association with and receives partial funding from the TIM program. 